\title{
Peat swamp forests in Borneo and Sumatra - Original state, development and disasters during the past 50 years with a proposal for future eco-resource management-
}

\author{
Isamu YAMADA \\ Center for Southeast Asian Studies, Kyoto University \\ 46 Shimoadachi-cho, Sakyo-ku, Kyoto, Japan. Tel: 075-464-8551 \\ E-mail: yamada8365@maia.eonet.ne.jp
}

\section{1) Sumatra, 1978}

My first experience in peat swamp forests was in Sumatra in 1978. During a mangrove survey in south Sumatra, I had a chance to see three types of development in the swampy area of the Musi River Basin (Yamada \& Sukardjo, 1979).

One was the large-scale development of the transmigration project in the major swampy area between Palembang and Sunsang. The project used heavy machinery to dig wide canals for drainage and irrigation. The original landscapes were totally transformed into very flat and devastated areas. At the time, the canals were already experiencing problems, causing the suspension of water flow. The site managers told me they were well aware of the problems, but because it was a government project, no one could stop it. Large-scale development has since proceeded rapidly, changing all the peat swamp forests into cultivated areas.

The second type of development I saw was in the Bugis settlement in Pulau Rimau. The Bugis came from Sulawesi to this part of Sumatra after the large trees were extracted in the early 1970s. They cut the remaining trees themselves, dug small canals, and developed the area little by little. Paddy nurseries were established on the dikes or on the floors of houses to escape damage by inundation. Rice was transplanted twice to ensure a better harvest. Peppers, sugar cane, fruit trees, and coconut palms were planted on higher ground near tree stumps. Although the movement was very slow, the homegrown development and cooperation of the Bugis villagers have changed the situation gradually; several years later, coconut palms had grown big enough to bear fruit and coconut sales provided the major income in the area. Compared with the first type, this villagelevel development pattern seemed better adapted to the difficult environmental problems of peat swamp forests (Furukawa, 1994).

The third type of development consisted of individual 
Table 1. Three types of development in the peat swamp forests in Sumatra in 1978.

\begin{tabular}{|c|c|c|c|}
\hline Level & Individual Household & Village & Company/Government \\
\hline Scale & Small & Medium & Large \\
\hline People & Individual & Villager & Company \\
\hline Labour & Single fighter & Community work & Mechanics \\
\hline Budget & None & Small & Big \\
\hline Destruction & Small & Small & Large \\
\hline Local knowledge & Enough & Enough & Poor \\
\hline Sustainability & Weak & Fair & Poor \\
\hline Future Perspectives & No & Yes & No \\
\hline Ecological balance & $\mathrm{Bad}$ & Good & $\mathrm{Bad}$ \\
\hline Integration & No & Good & No \\
\hline
\end{tabular}

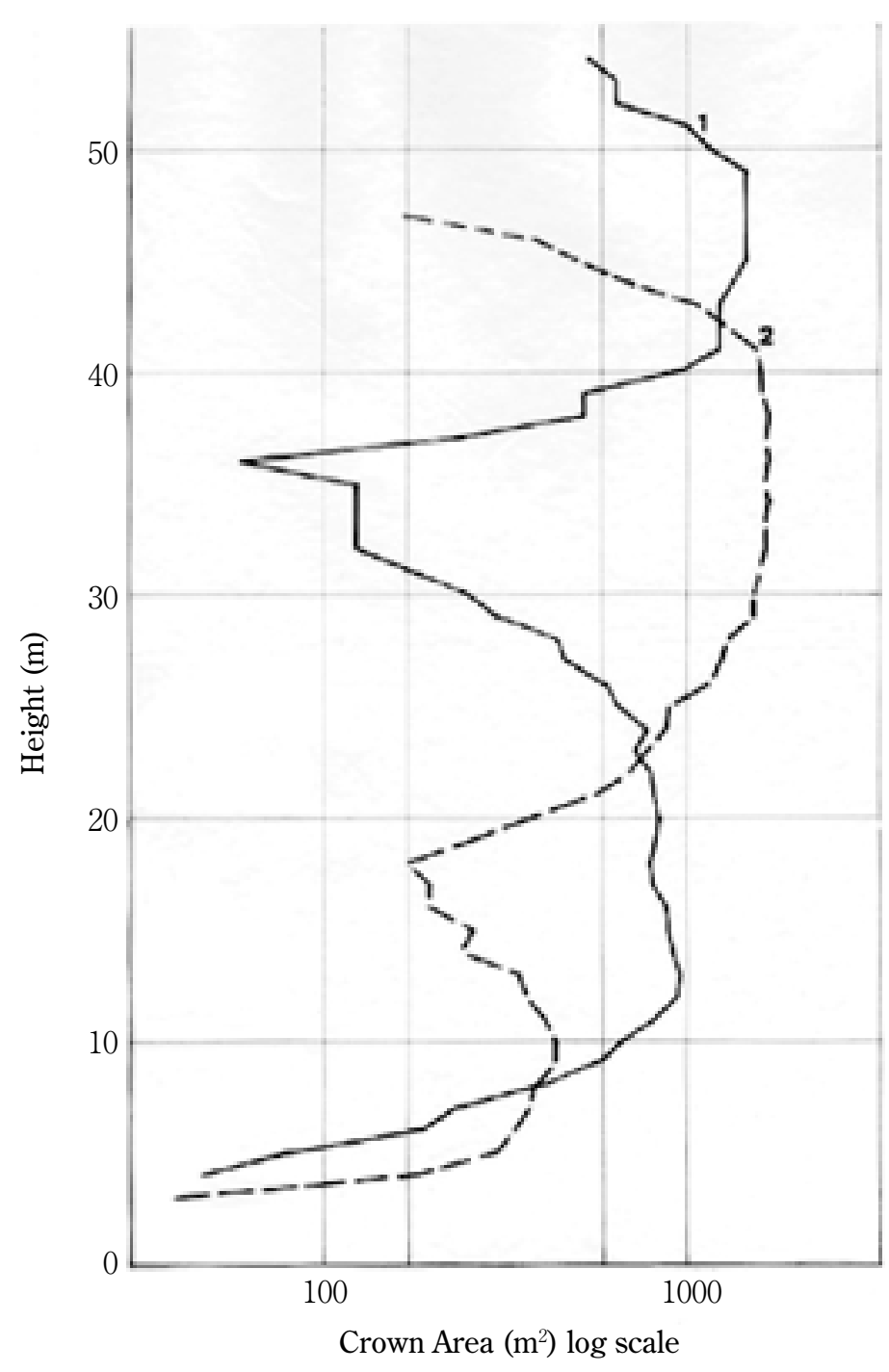

Fig. 1. Difference in canopy height of Alan bunga (2) and Alan batu (1). efforts to open up forest in order to cultivate land. This kind of effort was usually in vain, as cultivators were unable to surmount the environmental challenges of the area. The evidence found in south Sumatra in 1978 is summarized in Table 1.

\section{2) Brunei Forests, 1982-86}

Brunei is a small country located on the northwestern coast of Borneo island. Although the area is small, the forests of this country were in fairly good condition because oil and gas production produced enough wealth to spare the forest.

To commemorate the independence of Brunei from the United Kingdom, international cooperation between Brunei and Japan was inaugurated in 1984. The project was called the Forest Research Center Project and included basic forest ecological research, afforestation, and the conservation of genetic resources.

At that time, I was working at the Kanto Forest Tree Breeding Institute, a research institution working for genetic conservation and the promotion of tree breeding in Japan. I was dispatched to Brunei from 1984 to 1986 to help establish the cooperative project. During this time, I spent many days in the forests and made extensive surveys of various forest types, of which the peat swamp forests were the most important. 


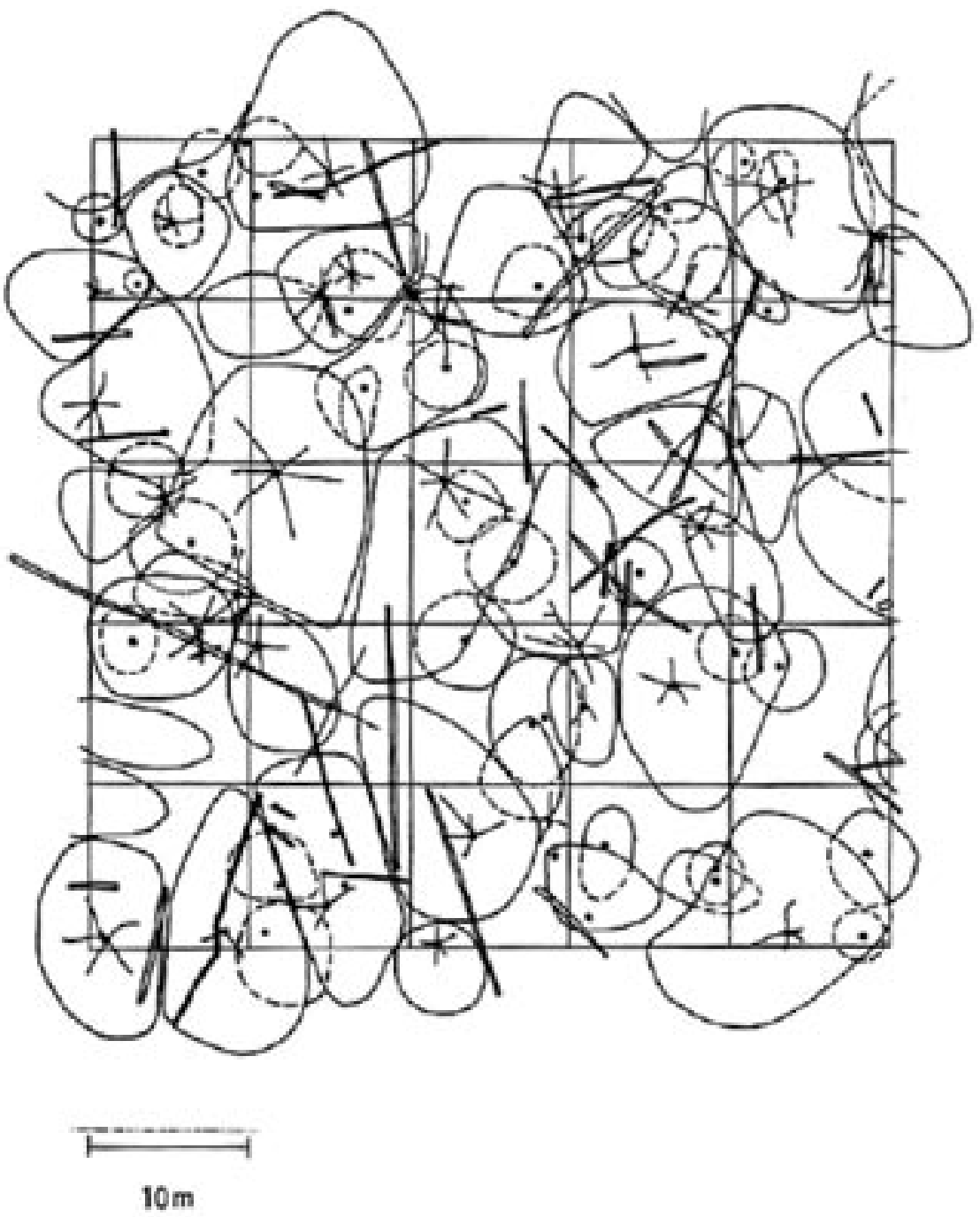

Fig. 2. Crown projection of the Alan bunga forest type in Brunei.

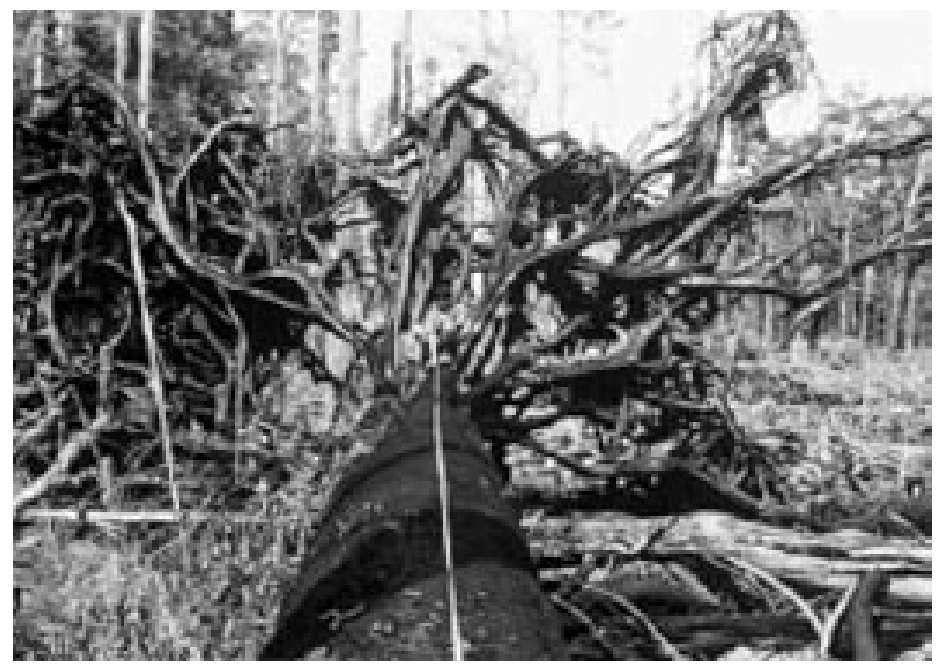

Fig. 3. Large root system of Alan batu 
Table 2. Summarized forest biomass in major forest types in Brunei.

\begin{tabular}{|l|c|c|c|c|c|c|}
\hline \multicolumn{1}{|c|}{ ForEST TYPE } & $\begin{array}{c}\text { PLOT SIZE } \\
\left(\mathrm{m}^{2}\right)\end{array}$ & No./ha & $\begin{array}{c}\text { BA./ha } \\
\left(\mathrm{m}^{2}\right)\end{array}$ & $\begin{array}{c}\text { SPECIES } \\
\text { No./plot }\end{array}$ & $\begin{array}{c}\text { HMAX } \\
(\mathrm{m})\end{array}$ & $\begin{array}{c}\text { DMAX } \\
(\mathrm{cm})\end{array}$ \\
\hline Agathis & $100 \times 50$ & 610 & 38.4 & 33 & 47.0 & 92.7 \\
Alan batu & $100 \times 50$ & 522 & 42.6 & 24 & 57.5 & 140.0 \\
Alan bunga & $100 \times 50$ & 310 & 43.4 & 22 & 51.5 & 96.6 \\
Alan & $50 \times 50$ & 400 & 50.7 & 14 & 51.0 & 80.5 \\
Padang alan & $50 \times 50$ & 872 & 39.7 & 17 & 43.5 & 63.5 \\
Alan padang & $50 \times 50$ & 744 & 34.5 & 10 & 33.0 & 46.0 \\
Ulat bulu & $50 \times 50$ & 1172 & 32.6 & 26 & 30.5 & 46.5 \\
Mixed peat swamp (1) & $50 \times 50$ & 828 & 36.5 & 41 & 36.0 & 73.3 \\
Mixed peat swamp (2) & $100 \times 100$ & 645 & 33.9 & 58 & 47.0 & 140.0 \\
Mixed dipterocarp & $100 \times 100$ & 736 & 49.4 & 174 & 50.0 & 114.0 \\
Kapor paya & $50 \times 50$ & 884 & 36.7 & 28 & 33.5 & 47.5 \\
\hline
\end{tabular}

Table 3. Candidate species for the reforestation of peat swamp forest by Anderson (1961)

Preferred species:

$\begin{array}{ll}\text { Ramin } & \text { (Gonystylus bancanus) } \\ \text { Jongkong } & \text { (Dactylocladus stenostachys) } \\ \text { Meranti lop } & \text { (Shorea scabrida) } \\ \text { Meranti lilin } & \text { (Shorea teysmanniana) } \\ \text { Meranti buaya } & \text { (Shorea rugosa var. uliginosa) } \\ \text { Meranti paya } & \text { (Shorea platycarpa) } \\ \text { Kapur paya } & \text { (Dryobalanops rappa) } \\ \text { Sepetir paya } & \text { (Copaifera palustris) } \\ \text { Semayor } & \text { (Shorea inaequilateralis) }\end{array}$

Acceptable species:

$\begin{array}{ll}\text { Jelutong } & \text { (Dyera lowii) } \\ \text { Perupok } & \text { (Lophopetalum multinervium) } \\ \text { Durian burong } & \text { (Durio carinatus) } \\ \text { Geronggang paya } & \text { (Cratoxylon arborescens) } \\ \text { Geronggang padang } & \text { (Cratoxylon glaucum) } \\ \text { Bintangor } & \text { (Calophyllum spp.) } \\ \text { Terentang } & \text { (Campnosperma coriacea) }\end{array}$

As already reported by Anderson (1961), Brunei and Sarawak have splendid tropical peat swamp forests. The most important tree species is Alan (Shorea albida), of which there are two important types. One is Alan bunga, a matured pure forest type with a $70-90 \mathrm{~cm}$ diameter and $50 \mathrm{~m}$ height; the other is Alan batu, an over-matured forest type with a diameter of at least $100-150 \mathrm{~cm}$ and a height of $70 \mathrm{~m}$. As shown in Fig. 1, the canopy class of each is quite different. Alan bunga has a uniform canopy projection, as shown in Fig. 2. The root system is very large, as shown in Fig. 3, and a pseudo-forest floor is established on the upper surface of the root mat. Leaves and fruits fall onto this pseudo-forest floor and decomposition occurs here. As shown in Table 2, the biomass of peat swamp forest types was as large as that of mixed dipterocarp forests. (Yamada, 1997)

Because the Alan bunga grow as pure stands, most of these areas became targets for harvesting. The method of harvest, performed by a contractor from Sarawak, was typical, using a small railway and the sliding sledge system. After cutting one site, the rail was removed and set up again in a neighboring logging site. 
Natural regeneration of Alan in the forest is very rare. The species is weakened by wind and attacked by insects called Ulat bulu and its flowering intervals are very long. In 1986, there was gregarious flowering in the Badas peat swamp area of southern Brunei, but regeneration was not successful. A plantation trial for this species was conducted in Sarawak, where good diameter growth rate of $10 \mathrm{~cm}$ was observed over 10 years. Vegetative propagation in a mist box has proven quite successful. Effective reforestation of Alan is one of the most important goals for this area.

Besides Alan, many other species have good reforestation potential in peat swamp forests. Anderson (1961) mentioned several candidates, as shown in Table

3. He also proposed preserving a series of peat swamp forest types and a strict nature reserve. But there are not many locations where we can find a series of each peat swamp forest type. In the Badas peat swamp area, the series was in good condition in the 1980s; it is doubtful whether it is still intact today. Even in Brunei, the pressure from private sector logging interests is very high.

In the 1960s and 1970s, peat area studies advanced greatly in Sarawak, leading many scientists to agree that it is better not to develop the deeper peat areas, but to conserve them as forests (Tropical Agriculture Research Center, 1980).

\section{3) Disasters in the late 1990s in Kalimantan}

In 1998, I joined the ITTO Forest Fire Prevention Mission to survey conditions in Kalimantan and Sarawak. This mission, organized by ITTO Head Quarters in Yokohama, included specialists from India, Nepal, Germany, and Japan. We conducted intensive interviews and observations in the areas studied and found the damaged forest to have many critical problems in the wake of fires. The forest fires first occurred on a huge scale in east Kalimantan in 1983 where 3 million ha of forest burned. Subsequently, several large fires occurred every 3 to 4 years; the fire in 1997 was especially severe on the peat swamp forest.

Simultaneously, a large-scale development project in central Kalimantan, called the "Mega Rice Project," started to open up large areas for cultivation. For this purpose, large canals were dug and new migrants were sent to the area. As is widely known, this project failed mainly due to poorly conceived canal design.

But other factors kept up the pressure. Large-scale fires spread into the peat areas and burned the remaining forests (Guhardja et al., 1993). Local autonomy became

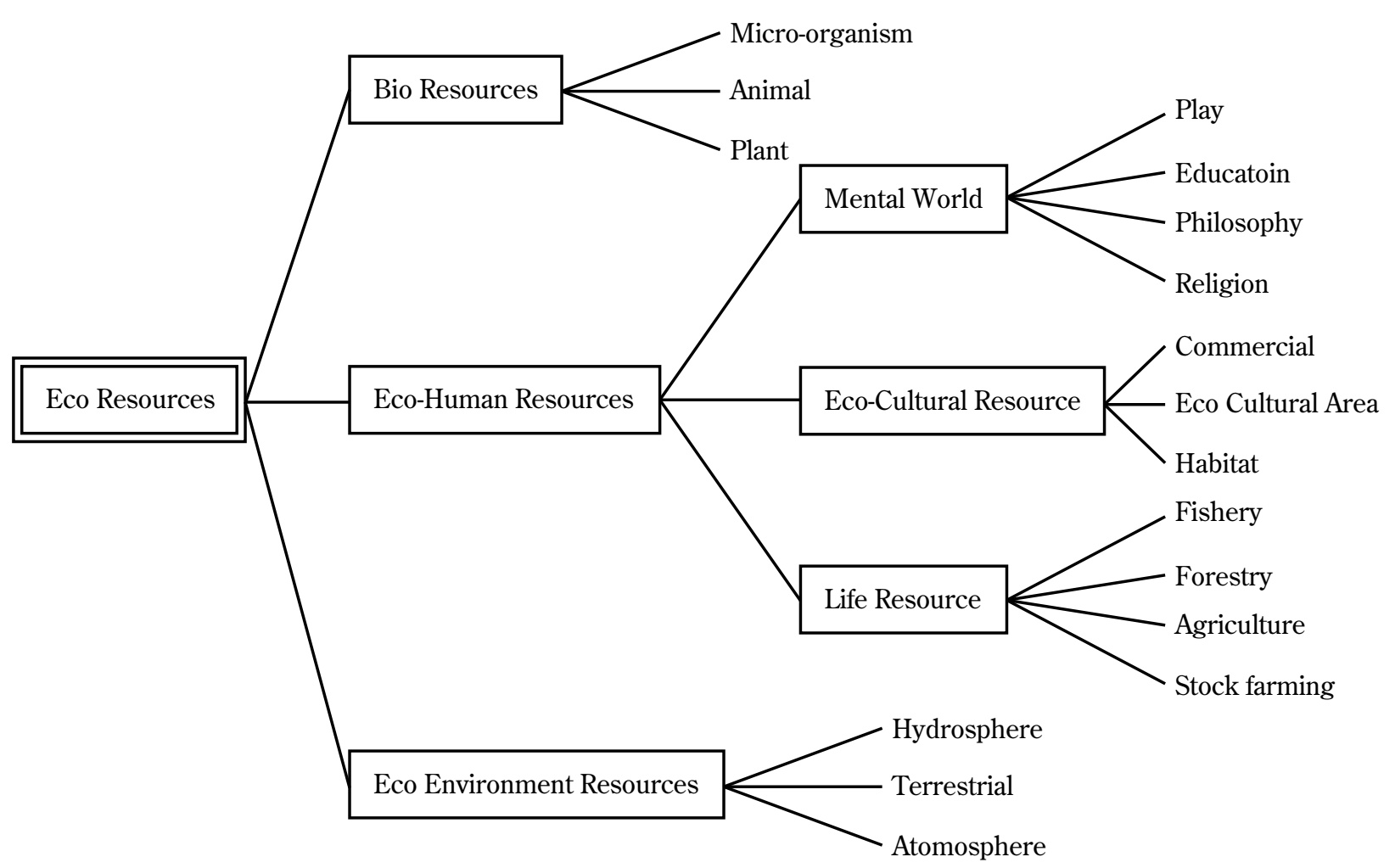

Fig. 4. Concept of eco-resources 
the dominant trend following the fall of President Suharto, allowing people more free access to logging than ever before. As we conducted surveys in the years from 1999 to 2001, we found the effects of these combined factors to be causing the forests to become more and more degraded.

\section{4) The concept of eco-resources: towards a harmonious life in the future}

Bio-science has become an advanced discipline in recent years, and the term "bio-resources" has become very common. Currently however, the concept does not include the entire ecosystem in which bio-resources live. A lack of ecosystem understanding and the wide-scale, speedy extraction of these resources have left devastated primary forests in many parts of the world. Obviously, bio-resources will not survive in the absence of suitable environmental conditions in particular ecosystems, but this simple argument has been ignored over the last two decades. If this trend continues, our bio-resources will be seriously threatened with extinction in the near future.

In contrast to this model of extraction and degradation, there are still many minority groups in the deep forests of Southeast Asia who live in a sustainable manner with a deep understanding of the natural environment (Sellato, 1994; Rousseau, 2000). The concept of "eco-resources" emerged from their examples and from my research experience in many parts of the world. The general concept is shown in Fig. 4. I divide ecoresources into three broad categories. First are the fundamental resources of atmosphere, soil, and water, which form our earth. Second are the so-called bioresources. Third are eco-human resources, the most important part of eco-resources.

In this category, I include the life resources of agriculture, forestry, fisheries, and stock farming. More important are anthropogenic factors such as culture, religion, healing, and so forth. Such cultural elements have been excluded from the nature preservation concept for many years, but recent trends have been changing.

For instance, religion has emerged as an important factor in protecting the forest in many Buddhist countries (Siam Society, 1989). Minority group traditions of preserving certain forests near their village as sacred places are also being recognized. And eco- tourism has become more and more attractive as people seek to spend time in natural sites to heal themselves from their exhausting urban lives (Fennell, 1999; Yamada, 2002).

This trend is completely different from the bioresources concept we know so far. Production is not important here because what we are seeking is unspoiled nature, not the extraction of bio-resources. The role of the forest has been changed from a source of resources to a preserver of harmonious pure nature. And this trend should be accelerated quickly because the pressure to destroy nature is ever more intense. What remains of pure nature will have elevated importance and value in the future. As shown in Fig. 4, it is important to include the whole ecosystem as well as the cultural and mental elements of human activities.

To see the concept of eco-resources in a particular area, Fig. 5 shows the concrete example of Brunei. This

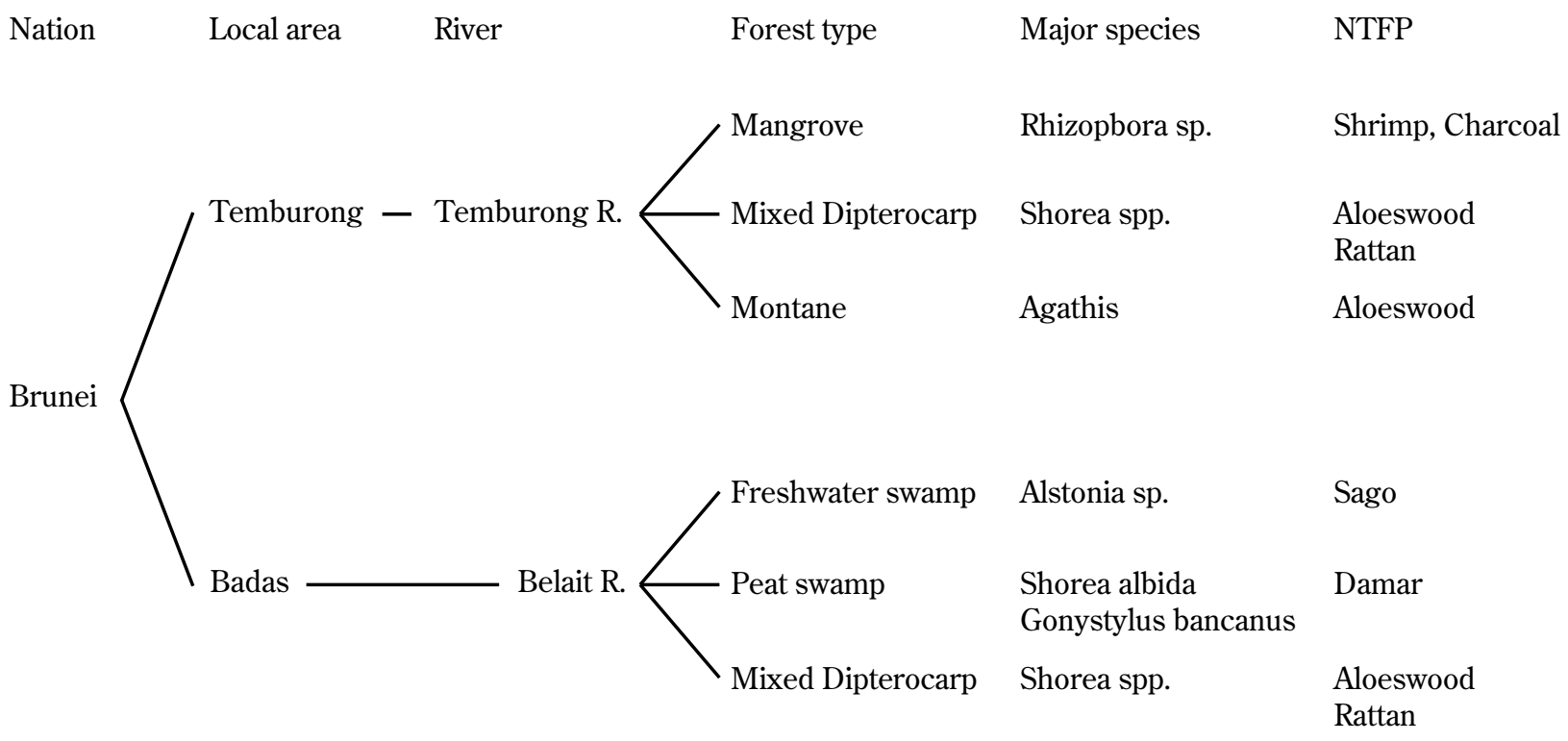

Fig. 5. Eco resources chart in Brunei. Only forest-related matters are shown. 


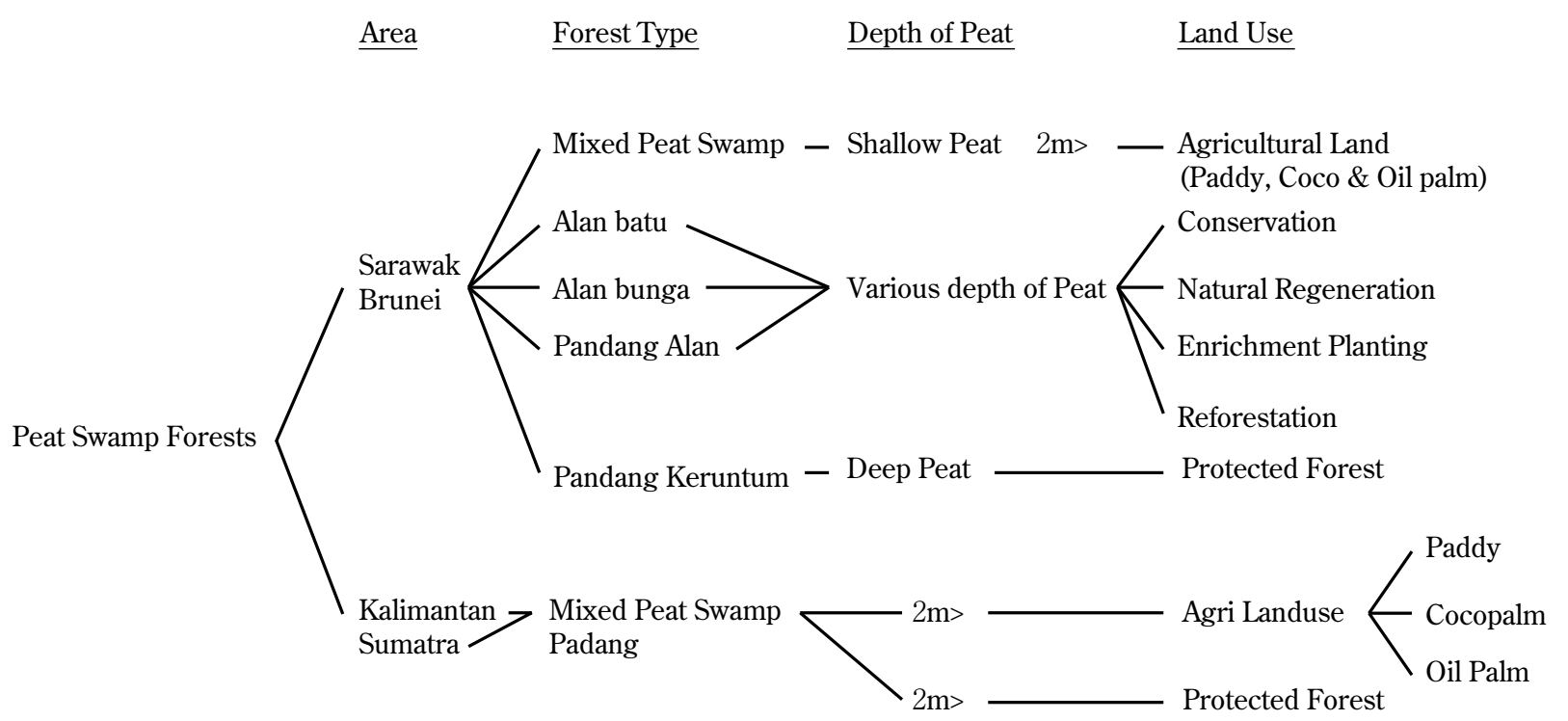

Fig. 6. Eco-resources chart for the peat swamp forests in Borneo and Sumatra. Forest types, depth of peat and possible land use.

is one example of a small area. By accumulating these data from many parts of the world, we can arrive at a broad view of the world's eco-resources and identify the fundamental principles of eco-resources as follows:

(1) Eco-resources are basically sustainable resources if no severe disturbance(s) occurs. Once disturbed, however, the cost of recovery is very high.

(2) The most highly diversified and rich ecoresources are found in the tropics. As we move toward the polar regions, eco-resources become uniform and show centralized distribution.

(3) The most fundamental types of eco-resources are found in primary nature, the opposite of which is the city.

(4) Anthropogenic factors are essential to the ecoresources concept in order to understand the relationship between humans and nature.

Looking back on the history of the earth, we see that human beings have been destroying nature for thousands of years. And some of the most severe destruction is ongoing in the peat swamp areas of Southeast Asia. Activities to date in Sumatra and Borneo have mostly destroyed the original natural systems and threaten the lives of people living in and around these areas. These are extremely wasteful activities because the original peat swamp forests were unique and are among the most valuable eco-resources on the planet.

This should not be disregarded: rehabilitation and protection of what remains is possible. Fig. 6 shows a tentative idea for land use according to peat depth. The integration of many disciplines will be necessary, but I believe that seeking a harmonious relationship between humans and nature in peat swamp areas is a most urgent task.

\section{REFERENCES}

Anderson, J. A. R. 1961. The ecology and forest types of the peat swamp forests of Sarawak and Brunei in relation to their silviculture. $\mathrm{Ph}$. D. thesis. Edinburgh University

Fennell, D. A. 1999. Ecotourism - An Introduction. Routledge

Furukawa, H. 1994. Coastal wetlands of Indonesia. Kyoto University Press, Japan

Guhardja, E., Fatawi, M., Sutisna, M., Mori, T. \& Ohta, S. (eds.) 1993. Rainforest ecosystems of East Kalimantan. Springer, Tokyo

Rousseau, J. 2000. Central Borneo -Ethnic Identity and Social Life in a Stratified Society, Clarendon Press, Oxford

Sellato, B. 1994. Nomads of the Borneo rainforest. University of Hawaii Press

The Siam Society, 1989. Culture and Environment in Thailand. The Siam Society, Thailand

Tropical Agriculture Research Center 1980. Swampy area in Southeast Asia. Tropical Agriculture Research Center, Norin Tokei Kyokai (in Japanese)

Yamada, I. 1997. Tropical rainforests of Southeast Asia. University of Hawaii Press 
Yamada, I. 2002. Ecotourism and eco-resources. Kagaku 72: 690-695. (in Japanese)

Yamada, I. \& Sukardjo, S. 1979. "Forest vegetation in swamp areas in south Sumatra" Southeast Asian Studies 17: 33-51. (In Japanese)

Received $5^{\text {th }}$ Mar. 2006

Accepted $19^{\text {th }}$ May 2006 